\title{
STUDY AND CHARACTERIZATION OF XENOLITHIC STRUCTURES TRAPPED IN GRANITIC MONUMENTS: A CASE STUDY
}

\author{
Hefni, Y. \\ Conservation dept, Faculty of Archaeology and Tourism Guidance, Misr Univ. for Science \& \\ Technology., $6^{\text {th }}$ October, Egypt \\ E-mail address: Yasser.shahin240@yahoo.com
}

\begin{tabular}{|c|c|}
\hline Article info. & EJARS - Vol. 11 (1) - June. 2021: 39-46 \\
\hline Article history: & Abstract: \\
\hline Received: $22-12-2020$ & Xenolithic structures are considered to be natural defects in the \\
\hline Accepted: 9-6-2021 & igneous rocks that highly affect their physicochemical and mechanical \\
\hline Doi: 10.21608/ejars.2021.179495 & $\begin{array}{l}\text { properties. They are foreign rock fragments trapped in the magma } \\
\text { or lava during the cooling process. They are totally unrelated to the } \\
\text { igneous rocks, as they compose from different types of rock pieces } \\
\text { that enclosed in the monumental granites during their emplacement. } \\
\text { This paper aims to study and characterize the xenolith fragment }\end{array}$ \\
\hline $\begin{array}{l}\text { Keywords: } \\
\text { Xenolith }\end{array}$ & $\begin{array}{l}\text { trapped in the studied granitic obelisk. The analytical study was } \\
\text { carried out using different techniques such as polarizing microscope, } \\
x \text {-ray diffraction, scanning electron microscope, EDS elemental }\end{array}$ \\
\hline Schist & analysis and BET surface area. The results clarified that the studied \\
\hline Granite & xenolith fragment is classified as biotite schist xenolith. In addition, it \\
\hline Obelisk & was observed that the xenolith fragment not only affects the \\
\hline Schistosity & $\begin{array}{l}\text { aestnetIc appearance of the stualed granitic obellsk but also It } \\
\text { represents a serious weakness point in its structure. }\end{array}$ \\
\hline
\end{tabular}

\section{Introduction}

Granite rock represents the most common intrusive igneous rock in the continental crust. It is formed through the cooling of magma at depth of the earth crust. As a result of the slow solidification of magma, granite usually has a coarse grained texture with visible and distinguishable individual minerals. It is mainly composed of quartz, alkali feldspars (microcline and orthoclase) and plagioclase feldspars (commonly albite and oligoclase), in addition to minor amounts of mica (biotite and muscovite), hornblende and other accessory minerals. The variety of the minerals present in granite gives it distinctive colors such as pink, white, gray and black [1-4]. Thanks to the unique physical and mechanical properties of granite. It was commonly used as an ornamental stone in the architectural and sculpture fields in ancient Egypt. Most of Egyptian archaeological sites contain both granitic sculptures and architectural elements such as statues, obelisks, columns, sarcophagi, stele, walls and lintels $[5,6]$. In Egypt, the main ancient quarries of granite are located in Aswan region along the eastern bank of the Nile, between the city of Aswan and Al-Shellal district as well as in some islands of the Nile such as Elephantine, Sehel and other islands $[7,8]$. It is well known that granitic rocks are subjected (during and after the natural occurrence) to complex processes which finally lead to formation of some geological defects such as joints, fractures, veins and xenoliths [9]. Xenoliths are foreign rock fragments trapped in igneous rocks during the cooling of magma or lava. They are totally unrelated to the igneous rocks, as they consist of different types of rock pieces that have 
fallen from the walls or roof of the magma chamber. Xenoliths are usually visible and easy to be recognized, due to their different compositions, colors and density than the host igneous rocks. Generally, they appear in different irregular shapes, but most of them are rounded, subrounded and angular. They range in size from small fragments (few centimeters) to very big blocks (several meters) [10-12]. Xenoliths are called cognate xenoliths or autoliths if they are derived from fragments genetically related to the host igneous rocks. The fragments of cognate xenoliths crystallized from the same magma of the enclosing rock, but at the early stage of crystallization. Xenoliths provide some valuable information on the composition and nature of basement in the inaccessible areas. They also present obvious examples of the complex interactions occurred in the underlying lithosphere (lower crust and upper mantle) [13,14]. Xenolithic structures are considered to be natural defects in the granitic rocks that highly affect their physicochemical and mechanical properties $[15,16]$. The ancient Egyptian sculptors and builders avoided using the defective granitic rocks in the fields of sculpting and architecture [17]. In rare cases, some sculptures and architectural elements were carved from granitic rocks containing xenoliths, fig. (1).

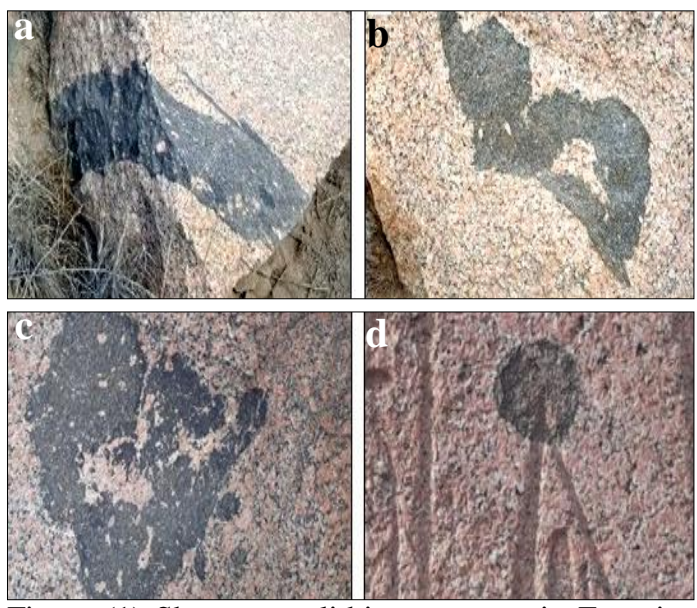

Figure (1) Shows xenolithic structures in Egyptian granitic monuments; $\underline{\mathbf{a}}$., $\underline{\mathbf{b}}$. granitic remains at the city of Bubastis; c., $\underline{\text { d. }}$ granitic remains at the city of Tanis.

It is worth mentioning that there are no detailed studies about the nature of xeno- liths appeared in Egyptian granitic monuments. The case study is a large piece of granitic obelisk related to the king Ramesses II, which was discovered in the temple of Amen at the archaeological city Tanis (San El-Hagar, Nile Delta, Egypt). The studied granitic obelisk represents one of the rare monuments that contain xenolithic structures, fig. (2). The main purpose of this work is to study and characterize the xenolith fragment trapped in the studied granitic obelisk. This study will provide good information about the nature of xenolith in addition to explain its effect on the granitic obelisk. Moreover, the results will help in making the future plan for restoration and conservation of the studied monument. The analytical study was carried out using different techniques such as polarizing microscope, $\mathrm{x}$-ray diffraction, scanning electron microscope, EDS elemental analysis and BET surface area.

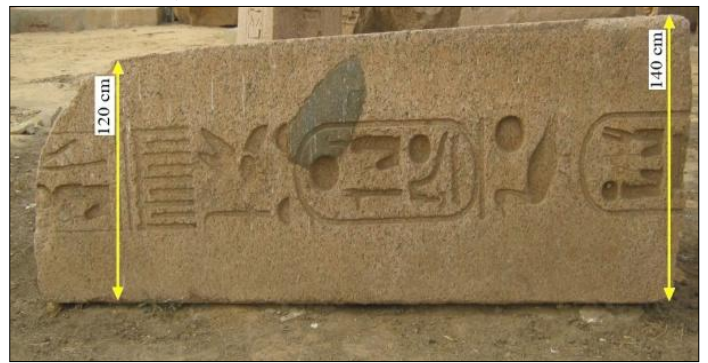

Figure (2) Shows xenolithic structure trapped in the studied granitic obelisk at Tanis.

\section{Materials and Methods}

\subsection{Sampling}

Small granitic samples were collected from the fallen fragments of the studied obelisk. In addition, micro-samples were carefully taken from the friable layers of the xenolithic structure.

\subsection{Polarized light microscope (PLM)}

Nikon eclipse LV10OPOL PLM was utilized to perform the petrographic study of the studied samples. In order to carry out the examination, the samples were prepared in the form of thin sections with thickness about 30 microns.

\subsection{X-ray diffraction analysis (XRD)}

The mineralogical characterizations of the studied xenolith and host granitic obelisk were studied using PANanalytical $x$-ray 
diffraction equipment model X'Pert PRO with using: Secondary Monochromator, $\mathrm{Cu}$ radiation $(1=1.542 \AA)$ at $45 \mathrm{~K}$.V., 35 M.A. and scanning speed $0.04 \%$ sec. The diffraction peaks between $2 \theta=2^{\circ}$ and $60^{\circ}$, corresponding spacing $(\mathrm{d}, \AA)$ and relative intensities $\left(\mathrm{I} / \mathrm{I}^{\circ}\right)$ were obtained. The diffraction charts and relative intensities are obtained and compared using the database software of International Centre for Diffraction Data $(I C D D)$.

\subsection{Scanning electron microscope (SEM-EDS)}

The morphological features of the studied samples were investigated using VEGA3 TESCAN scanning electron microscope. In addition, the elemental compositions of the same samples were determined using the energy dispersive spectrometer (EDS) connected to this microscope.

\subsection{Brunauer-Emmett-Teller technique (BET)}

Surface areas of the granitic obelisk and xenolith were measured based on the methodology of Brunauer-Emmett-Teller (BET) using Quantachrome Touchwin v1.2 instrument after degassing under $\mathrm{N}_{2}$ flow for 18 h. at $90{ }^{\circ} \mathrm{C}$ [18].

\section{Results}

\subsection{Petrographic study}

The petrographical study of the granitic obelisk and its xenolithic structure proved that the obelisk was sculpted from coarse grained granite. The granitic type is mainly composed of potash feldspars (microcline and orthoclase perthite), quartz and plagioclase feldspar associated with considerable amounts of biotite and hornblende. In addition, trace amounts of sphene, zircon and opaque minerals were detected. Potash feldspars (microcline and orthoclase perthite) are the most common constituents of the rock. They appear with medium to coarsegrained, generally subhedral to anhedral crystals and slightly altered to sericite. Plagioclase (albite) occurs as subhedral to euhedral crystals with albite twinning. Quartz appears with fine to medium-grained, anhedral crystals. It occurs as crystal agg- regates that fill in the interstitial spaces between feldspar and mica crystals. Biotite exists in small amount as fine to mediumgrained, flaky crystals in the interstices of feldspars and quartz. It suffers from surficial corrosion and partial alteration to iron oxides. Hornblende presents as fine to medium-grained crystals, associated with biotite. It is slightly converted to iron oxides. Moreover, quartz, feldspars and biotite are generally fractured and sutured due to weathering processes, fig. (3-a ,b, c, d).

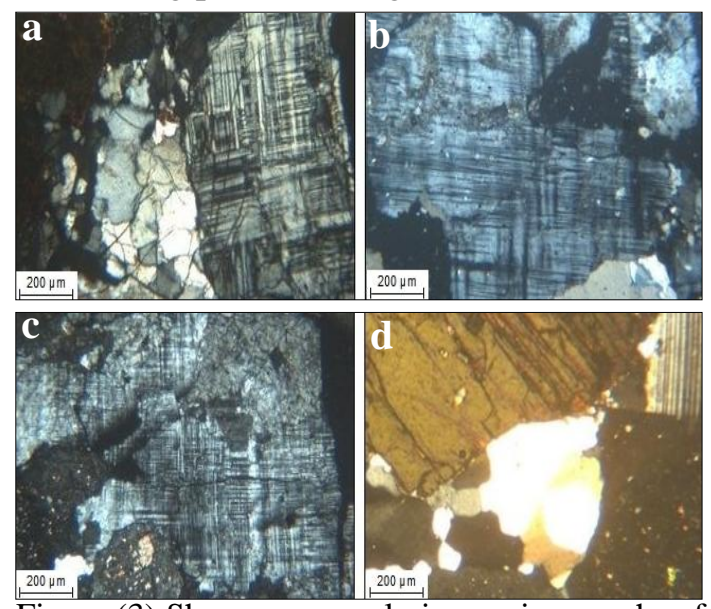

Figure (3) Shows cross-polarisers micrographs of the granitic obelisk; a. micro cracks of quartz and microcline, b. microcline and orthoclase showing perthitic texture, c. partial alteration of orthoclase into sericite, $\underline{\mathbf{d}}$. high deformation of biotite.

Based on the petrographic study, fig. (4$\mathrm{a}, \mathrm{b}, \mathrm{c}, \mathrm{d})$ the xenolith fragment can be classified as biotite schist. The sample is principally comprised of biotite, plagioclase, quartz and hornblende. Trace amounts of sphene, muscovite and opaque minerals were also existed. These minerals are arranged in parallel alignment forming schistose texture. Biotite occurs as medium-grained to very fine anhedral to subhedral aggregates. It is partially to highly altered to sericite, chlorite and iron oxides in the cleavage planes and borders. Plagioclase presents as fine to coarse-grained, subhedral to euhedral crystals. It is partially and highly altered to sericite. Some plagioclase crystals are slightly elongated in the direction of schistosity. Quartz exists as very fine to mediumgrained, anhedral, interlocked crystals. Some quartz crystals are stretched along the direction of schistosity. Hornblende exists 
as fine-grained, subhedral prismatic crystals and commonly associated with biotite. It is partially altered to iron oxides in the cleavage planes and borders. Opaque minerals occur in minor amounts as fine to very fine-grained, anhedral to subhedral crystals.
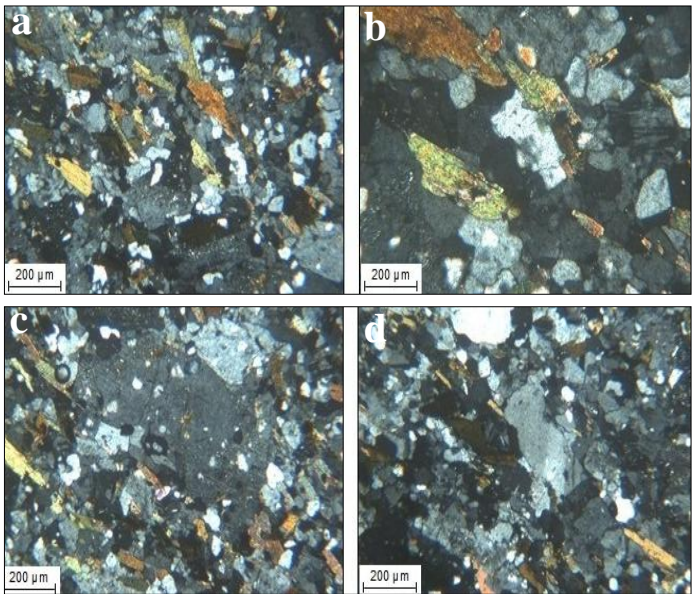

Figure (4) Shows cross-polarisers micrographs of xenolith trapped in the granitic obelisk; a. parallel alignment of minerals displaying schistose texture, $\underline{\mathbf{b}}$. plagioclase is altered to sericite and biotite is altered to sericite, chlorite and iron oxides, $\underline{\mathbf{c}}$. partial alteration of plagioclase to sericite, $\underline{\mathbf{d}}$. elongation of quartz in the direction of schistosity.

\subsection{Mineralogical characterization}

XRD pattern of the granitic obelisk, fig. (5-a) shows that it is composed of microcline, albite and quartz as main minerals. In addition, small amounts of biotite and hornblende are also detected. On the other hand, XRD pattern of the studied xenolith, fig. (5-b) declares that biotite, albite, quartz and hornblende are the primary and most abundant minerals. Furthermore, the minerals of sericite, dolomite and hematite were detected as secondary weathering products. Approximate percentages of the minerals detected in the studied samples are summarized in tab. (1).

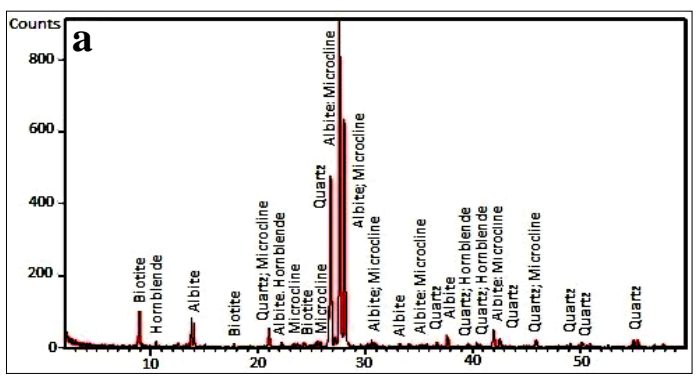

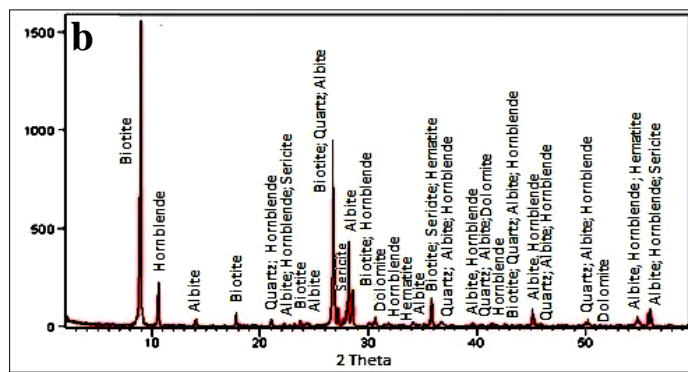

Figure (5) Shows X-ray diffraction patterns of $\underline{\text { a. }}$ granitic obelisk, b. xenolithic structure.

Table (1) Approximate percentages of the minerals detected in the studied samples.

\begin{tabular}{lcc}
\hline Minerals & \multicolumn{2}{c}{ Approx. percentages } \\
\cline { 2 - 3 } Microcline & Granitic sample & Xenolithic sample \\
Albite & 33 & 00 \\
Quartz & 39 & 25 \\
Biotite & 19 & 15 \\
Hornblende & 06 & 40 \\
Sericite & 03 & 10 \\
Dolomite & 00 & 05 \\
\hline Hematite & 00 & 02 \\
\hline
\end{tabular}

\subsection{Morphological and elemental characterization}

The morphological features of the studied granitic obelisk and its xenolithic structure using SEM reveal that, on one hand, the granitic sample, fig. (6-a, b) has no significant mineralogical alterations occurred in the primary minerals. Surficial corrosion and tiny cracks were found as mechanical deterioration aspects. On the other hand, SEM micrographs of the xenolithic structure, fig. $(6-c, d)$ indicate that it highly suffers from mechanical and physiochemical weathering. The sample appears to be very fragile and has many voids, micro-cracks, fissures, flakes, etch-pits and weathering products. These results illustrate the high weakness grade of the studied xenolith.
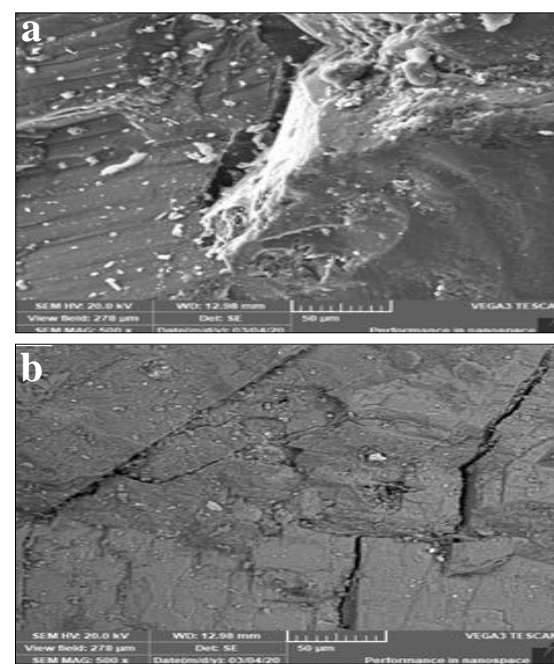

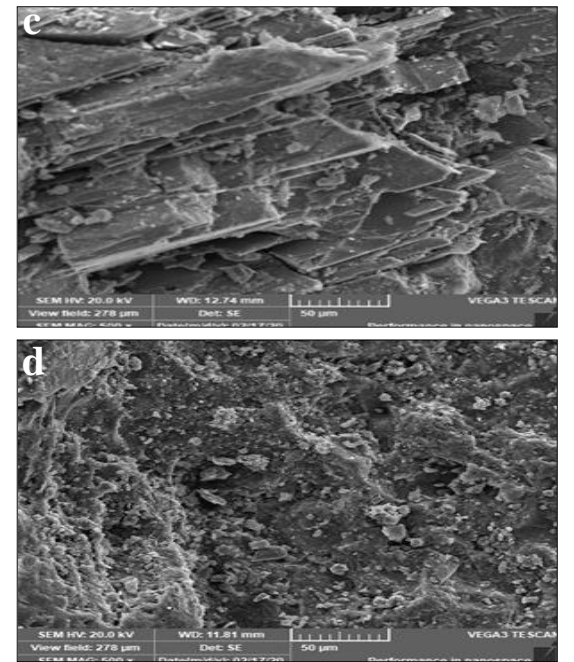

Figure (6) Shows SEM micrographs of the studied sample; a.., $\underline{\mathbf{b}}$. surficial corrosion, cracks and pits of granite samples, $\underline{\mathbf{c}}$., $\underline{\mathbf{d}}$. xenolithic structure with very fragile surface with flakes, micro cracks, voids, etch-pits and surficial deformation accumulation of weathering products on the surficial layer.

Furthermore, the elemental analysis of the same granitic sample clarifies that it is composed of ( $\mathrm{Si}, \mathrm{O}, \mathrm{Al}, \mathrm{Fe}, \mathrm{Na}, \mathrm{K}, \mathrm{Mg}$, $\mathrm{Ca}$ and $\mathrm{Ti}$ ). Within the same context, the elemental composition of the same xenolith sample includes $(\mathrm{O}, \mathrm{Fe}, \mathrm{Si}, \mathrm{Ca}, \mathrm{C}, \mathrm{Al}, \mathrm{Mg}$, $\mathrm{K}, \mathrm{Na}$, and $\mathrm{Ti}$ ), all of these results are listed in tab. (2)

Table (2) EDS results of the granitic sample and studied xenolithic structure.

\begin{tabular}{lcc}
\hline Elements (wt \%) & Granitic sample & Xenolithic structure \\
\hline $\mathrm{Si}$ & 49.45 & 15.30 \\
$\mathrm{O}$ & 32.80 & 40.60 \\
$\mathrm{Al}$ & 09.60 & 04.80 \\
$\mathrm{C}$ & - & 05.90 \\
$\mathrm{Fe}$ & 03.50 & 16.60 \\
$\mathrm{Na}$ & 01.50 & 01.90 \\
$\mathbf{K}$ & 01.10 & 03.80 \\
$\mathrm{Mg}$ & 00.80 & 03.50 \\
$\mathrm{Ca}$ & 00.70 & 06.70 \\
$\mathrm{Ti}$ & 00.55 & 00.90 \\
Total & $100 \%$ & $100 \%$ \\
\hline
\end{tabular}

\subsection{Specific surface area}

Determination of specific surface areas of stones provides a real indication about the state of their outer surfaces $[19,20]$. The technique of BET represents one of the most common methods used to measure surface area, so that it was employed to comparatively quantify the surface areas of the studied granitic and xenolithic samples. The values of specific surface areas of the studied samples are reported in tab. (3).
Table (3) Results of specific surface areas.

\begin{tabular}{lc}
\hline Sample & Specific surface area $\left(\mathbf{m}^{2} / \mathbf{g}\right)$ \\
\hline Granite & 03.5009 \\
\hline Xenolith & 19.2297 \\
\hline
\end{tabular}

\section{Discussion}

Based on the field observations, the studied granite possess relatively resistance and durability against deterioration factors, as the obelisk appears to be in good state of preservation. The results of petrographic study showed that the studied granite is mainly composed of potash feldspars, quartz and albite in addition to small amounts of biotite and hornblende. According to PLM micrographs, potash and plagioclase feldspars are slightly altered to sericite while biotite is slightly altered to iron oxides. These alteration products weren't detected by XRD due to their low concentrations. SEM micrographs of granitic sample showed that no obvious mineralogical changes occurred in the primary minerals. Some tiny cracks and surficial deformation were observed by SEM. BET analysis indicated low specific surface area of the studied granite that reflects the low grade of weathering. On the other hand, the visual inspection clarified that the studied xenolith has a dark-gray color and oval shape with dimensions $60 \times 30 \mathrm{~cm}$. The results of the current work confirmed that the xenolith trapped in the obelisk is classified as biotite schist. Schists are metamorphic rocks formed by the metamorphosis of mudstone and shale. Schists are foliated rocks and have medium to coarse-grained features. In rare cases, they are derived from the conversion of some types of igneous rocks such as granite and basalt. They are mainly composed of platy mica minerals aligned in parallel lines exhibiting a distinct foliated texture which is known as schistosity. In addition, quartz, feldspars and hornblende are commonly occurred in schists. The mineral grains of schist are large enough to be recognized by naked eye. Schists are usually classified and named depending on their main constituent minerals. For example, 
schists mainly composed of muscovite and biotite are called mica schists [12,21-23]. As demonstrated by the petrological microscope, the studied biotite schist is principally composed of biotite, albite, hornblende and quartz. In addition, this examination accentuated the partial conversion of albite into sericite as well as the alteration of biotite into sericite, chlorite and iron oxides. XRD analysis of the xenolithic sample elucidated that it is mainly comprised of biotite, albite, quartz and hornblende in addition to sericite, dolomite and hematite as weathering products. Furthermore, EDS elemental analysis emphasized the presence of dolomite by detecting the carbon element, in addition to calcium, magnesium, and oxygen. SEM micrographs declared that studied xenolithic structure highly suffers from surficial deformation and has a lot of voids, flakes, microcracks, fissures, etch-pits. In addition, it contains many features of mineralogical alteration. This result agrees with the high value of surface area of the xenolith sample, which also refers to the porosity high level. Depending on the field observations and analytical studies, the studied xenolithic structure has highly affected by physiochemical weathering. Physiochemical weathering of stones is a complex processes caused by the combination of physical (e.g., rain, relative humidity, temperature) and chemical (e.g., atmospheric pollutions) factors [24-26]. Indeed, physiochemical weathering has played the fundamental role in mineralogical alteration of the constituent minerals of xenolithic structure. Formation of sericite is ascribed to the hydrolysis of biotite and albite under the impact of water and acidic solutions [27,28]. In addition, biotite and hornblende are altered into chlorite and iron oxides [27,29,30]. Moreover, it can be suggested that the existence of dolomite in the studied xenolith is a result of the hydrothermal alteration of hornblende [31]. Notable, the abundance of biotite in the studied schist xenolith has increased its susceptibility to deterioration; this is due to the low stability of biotite against weathering processes. Alteration of biotite grains is associated with their expansion along cleavage planes and grain boundaries [3234]. This expansion generates internal mechanical stresses which highly affect the surrounding minerals, leading to cracking, surficial deformation, granular disintegration and finally flaking of superficial layer, fig. (7). Furthermore, daily and seasonal variation of air temperature has contributed to the mechanical damage of xenolith [35]. These deterioration mechanisms led to the increase of porosity and surface roughness of xenolith, which caused its high surface area as observed by BET technique. High porosity of xenolith allows water to permeate through the outer layer, accelerating the physiochemical and microbiological deterioration factors $[36,37]$. It is worth noting that the characteristic schistose texture allows schist to be easily broken into very thin fragile flakes parallel to the schistosity $[12,23]$. Ultimately, the studied biotite shist xenolith is a very weak rock and more susceptible to damage comparing with its host granite.

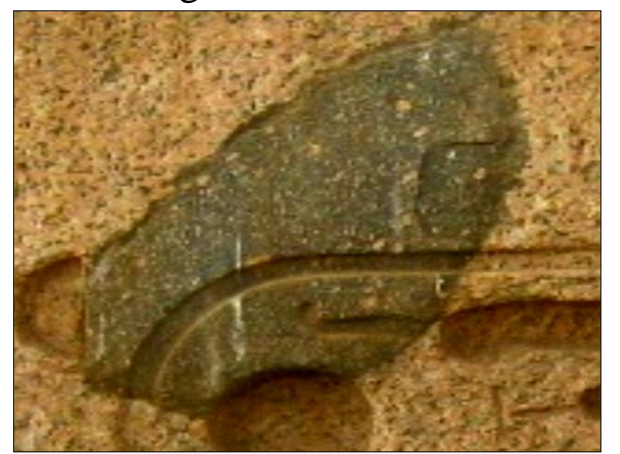

Figure (7) Shows the studied xenolith suffers from etch-pits, surficial deformation, flaking and erosion.

\section{Conclusion}

The studied obelisk is a rare Egyptian granitic monument that contains xenolith fragment. The results declared that the studied xenolith is classified as biotite schist xenolith. The xenolith not only affects the aesthetic appearance of the granitic obelisk but also it represents a major weakness point in its structure. The different properties of the xenolith and the host granitic obelisk, depending on their different mineralogical compositions, result in many degradation processes. Due to the poor properties of biotite schist, it is deteriorated more rapidly than its host granitic obelisk. Finally, 
it can be suggested that the presence of xenolith fragment inside the granitic obelisk is considered to be a natural defect and works as an endogenous deterioration factor.

\section{References}

[1] Twidale, C. (1982). Granite landforms, Elsevier, Amsterdam.

[2] Pitcher, W. (1997). The nature and origin of granite, $2^{\text {nd }}$ ed., Chapman \& Hall, London.

[3] Cefrey, H. (2003). Igneous rocks, Rosen Pub. Group, NY.

[4] Haldar, S. \& Tisljar, J. (2014). Introduction to mineralogy and petrology, Elsevier, Amsterdam.

[5] Helmi, F. \& Hefni, Y. (2016). Nanocomposites for the protection of granitic obelisks at Tanis, Egypt, MAA, Vol. 16, (2), pp. 87-96.

[6] El-Badry, A. (2018). Environmental degradation of granite stoneworks, Karnak temples, Egypt, Int. J. of Chem Tech Research, Vol. 11 (9), pp. 340-352.

[7] Aston, B., Harrell, J. \& Shaw, I. (2000). Stone, in: Nicholson, P. \& Shaw, I. (eds.) Ancient Egyptian Materials and Technology, Cambridge Univ. Press, pp. 5-77.

[8] Klemm, D. \& Klemm, R. (2001). The building stones of ancient Egypt - a gift of its geology, J. of African Earth Sciences, Vol. 33, pp. 631-642.

[9] Reddy, D. (2002). Evaluation of natural defects in commercial decorative rock deposits in Karnataka, India, Gondwana Research, Vol. 5 (2), pp. 557-560.

[10] Tyrrell, G. (1978). The principles of petrology: an introduction to the science of rocks, Chapman \& Hall Ltd, London.

[11] Cobbing, J. (2000). The geology and mapping of granite batholiths, SpringerVerlag, Germany.

[12] Montgomery, C. (1990). Physical geo$\operatorname{logy}, 2^{\text {nd }}$ ed., Wm. C. Brown Pub., USA.

[13] Horvath, A., Kristaly, F. \& Less, G. (2013). Xenoliths and enclaves from the Miocene volcanic rocks of Tok- ajmts, Geosciences and Engineering, Vol. 2 (4), pp. 7-26.

[14] Yoshinobu, A., Wolak, J., Paterson, S., et al. (2009). Determining relative magma and host rock xenolith rheology during magmatic fabric formation in plutons: Examples from the middle and upper crust, Geosphere, Vol. 5 (3), pp. 270-285.

[15] Reddy, D. (2010). Engineering geo$\operatorname{logy}, 1^{\text {st }}$ ed., Vikas Pub. House Pvt Ltd, India.

[16] Mangunatha, B., Reddy, V., Krishnakumar, K., et al. (2014). Selection criteria for decorative dimension stones, Int. J. of Earth Sciences and Engineering, Vol. 7 (2), pp. 408414.

[17] Kelany, A., Negem, M., Tohami, A., et al. (2009). Granite quarry survey in the Aswan region, Egypt: Shedding new light on ancient quarrying, in: Abu-Japer, N., Bloxam, E., Degryse, P., et al. (eds.) QuarryScapes: Ancient stone quarry landscapes in the eastern Mediterranean, Special Pub., Vol. 12, Geological Survey, Norway, pp. 87-98.

[18] Giménez, R., Mencia, R., Garcia, I., et al. (2013). Alteration processes of historical granitic rock found in Avila, Spain, MAA, Vol. 13 (1), pp. 107-115.

[19]Alayande, S., Mubiayi, M., Makhatha, M., et al. (2015). Experimental characterization of physicochemical and geological properties of granite from Olowu, Ibadan, Oyo State, Nigeria, in: Chaouki, J. \& Zhao, Y (eds.) Proc. of The World Congress on Mechanical, Chemical, and Material Engineering, No. 337, Int. ASET Inc., Spain, pp: 1-9.

[20] Anovitz, L. \& Cole, D. (2015). Characterization and analysis of porosity and pore structures, Reviews in Mineralogy and Geochemistry, Vol. 80, pp. 61-164.

[21]Press, F. \& Siever, R. (1978). Earth, $2^{\text {nd }}$ ed., W. H. Freeman and Comp., USA. 
[22] Ramsey, W., Philips, C. \& Watenpaugh, F. (1979). Modern earth science, Holt, Rinehart and Winston Pub., USA.

[23] Foster, R. (1983). General geology, $4^{\text {th }}$ ed., Bell \& Howell Comp., USA.

[24] Wongfun, N., Plötze, M., Furrer, G., et al. (2010). Weathering of granite from the Damma glacier area: The contribution of cyanogenic bacteria, J. of Geomicrobiology, Vol. 31, pp. 93-100.

[25]El-Gohary, M. (2011). Analytical investigations of disintegrated granite surface from the unfinished obelisk in Aswan, J. of ArchaeoScience, Vol. 35, pp. 29-39.

[26] Gour, D., Soumendu, Ch. \& Nilanjana, D. (2014). Weathering and mineralogical alteration of granitic rocks in Southern Purulia district, West Bengal, India, Int. Research J. of Earth Sciences, Vol. 2, pp. 1-12.

[27] Abdelrahim, Sh. (2006). Study the deterioration of granite statues, Keman Fares excavations, Fayoum, Egypt, J. of Engineering Sciences, Vol. 34 (1), pp. 283-298.

[28]El-Gohary, M. (2012). The environmental factors affecting the archaeological buildings in Egypt-I, in: Olszewska-Świetlik, J., Arszyńska, J. \& Szmelter-Fausek, B. (eds.) Interdisciplinary Research on the Works of Art, Uniwersytetu Mikołaja Kopernika, Torun, Poland, pp. 151-165

[29] Mortimer, N. \& Little, T. (1998). Altered biotites in the Marlborough schist, New Zealand, New Zealand J. of Geology and Geophysics, Vol. 41, pp. 105-109.

[30] Wilson, M. \& Farmer, V. (1970). A study of weathering in a soil derived from a biotite-hornblende rock II. The weathering of hornblende, Clay Minerals, Vol. 8, pp. 435-444.
[31] Kirsimae, K., Suuroja, S., Kirs, J., et al. (2002). Hornblende alteration and fluid inclusions in Kardla impact crater, Estonia: Evidence for impactinduced hydrothermal activity, Meteoritics \& Planetary Science, Vol. 37, pp. 449-457.

[32] Matias. J. \& Alves. C. (2001). Decay patterns of granite stones in Braga monuments (NW Portugal), in: Lourenco, P. \& Roca. P. (eds.) Historical Constructions, Guimarães, Portugal, pp. 363-371.

[33]Akesson. U., Stigh. J., Lindqvist. J., et al. (2003). The influence of foliation on the fragility of granitic rocks, assessed with image analysis and quantitative microscopy, Engineering Geology, Vol. 68 (3-4), pp. 275-288.

[34]Lopez-Arce, P., Varas-Muriel, M., Fernandez-Revuelta, B., et al. (2010). Artificial weathering of Spanish granites subjected to salt crystallization tests: Surface roughness quantification, Catena, Vol. 83, pp. 170-185.

[35]Helmi, F. (1985) Deterioration of some granite in Egypt, in: Felix, G. (ed.) Proc. of the $5^{\text {th }}$ Int. Cong. on Deterioration and Conservation of Stone, Polytechniques Romandes, Lausanne, pp. 421-429.

[36] Sousa, L., Suarez del Rio, L., Calleja, L., et al. (2005). Influence of micro fractures and porosity on the physicomechanical properties and weathering of ornamental granites, Engineering Geology, Vol. 77, pp. 153-168.

[37]Rosener, M. \& Geraud, Y. (2007). Using physical properties to understand the porosity network geometry evolution in gradually altered granites in damage zones, in: David, C. \& Le Ravalec-Dupin, M. (eds.) Rock Physics and Geomechanics in the Study of Reservoirs and Repositories, Vol. 284, Special Pub., Geological Society, London, pp. 175-184. 